\title{
Influence of the moisture content of forest tree pollen on its response to different viability tests
}

\author{
J. Webber ${ }^{1}$ and M. Bonnet-Masimbert ${ }^{2}$ \\ 1 Research Branch, British Columbia Ministry of Forests, Victoria, Canada, and \\ 2 INRA, Station d'Amélioration des Arbres Forestiers, Ardon, 45160 Olivet, France
}

\section{Introduction}

Pollen management has become an integral part of intensive tree improvement, especially for facilitating breeding programs and improving both orchard yields and genetic efficiency. To handle pollen successfully, particularly its storage, drying to moisture contents of less than $10 \%$ is required (Webber, 1987; and unpublished data). However, in certain angiosperms, dehydration can have a detrimental effect on pollen germination and vigor which is only restored by rehydration (Shivanna and Heslop-Harrison, 1981).

The cause of this reduction in germination and viability with dehydration is not fully understood but loss of membrane integrity may be involved (Shivanna and Heslop-Harrison, 1981). Certainly, it is a principal factor in the loss of vigor in corn (Kerhoas, et al., 1987).

In this paper, data from previous experiments are summarized to show the factors affecting reactivation of pollen vigor, and data from recent tests, which demonstrate the effect of rehydration atmosphere (humidity, temperature and exposure time) on in vitro viability response, are shown.

\section{Materials and Methods}

Procedures for testing in vitro viability have been described by Charpentier and BonnetMasimbert (1983) and Webber (1987). The effect of 2 relative humidities ( 70 and $100 \% \mathrm{RH}$ ) and 3 temperatures $\left(10,20\right.$ and $\left.30^{\circ} \mathrm{C}\right)$ on rehydration of Douglas fir (Pseudotsuga menziesii) pollen and their effects on germination and conductivity over 9 exposure times $(0,3,6$, $16,24,48,72,96$ and $120 \mathrm{~h}$ ) were tested. The $70 \% \mathrm{RH}$ was generated by controlling wetbulb/dry-bulb temperatures using a water bath (T1) and an incubator (T2). The $100 \% \mathrm{RH}$ was created by saturating air in a closed container maintained at the incubator temperature $T 2$.

Germination of Douglas fir pollen was assessed for class 1 grains (defined as elongation more than twice the original diameter of the grain) after $48 \mathrm{~h}$ of incubation and expressed as a percentage of the total number of pollen grains observed. Conductivity was determined using $25 \mathrm{mg}$ of pollen in $7.5 \mathrm{ml}$ of ultra-pure $\mathrm{H}_{2} \mathrm{O}$ and measured after $1 \mathrm{~h}$ at $25^{\circ} \mathrm{C}$ (cold leachate). 


\section{Results}

\section{Correlation analysis for Douglas fir pollen}

Table I summarizes the correlation coefficients between 3 in vitro assays (respiration, conductivity and germination) and percent filled seeds per cone ( $\% F s p c)$ for Douglas fir pollen. It is apparent that respiration is less sensitive to the moisture content or hydration state. However, conductivity and most certainly germination are very sensitive, showing significant improvement inc correlation coefficients with either increasing initial moisture content (MC) or hydration state.

Hydration effects on assay responses of Douglas fir pollen

Fig. 1 shows the average response of 3 Douglas fir pollen lots to conductivity and germination tests after hydration in 2 humidities at 10,20 and $30^{\circ} \mathrm{C}$. At $70 \%$ $\mathrm{RH}$, average $\mathrm{MC}$ was about $11 \%$, whereas, at $100 \% \mathrm{RH}, \mathrm{MC}$ increased to about $48 \%$. Conductivity was affected by both humidity and temperature. At $70 \%$ $\mathrm{RH}$, conductivity values increased (par- ticularly at $30^{\circ} \mathrm{C}$ ), suggesting that membrane reorganization was incomplete. However, at $100 \% \mathrm{RH}$, membranes appeared to stabilize early and conductivity values remained relatively stable, at least up to $72 \mathrm{~h}$, after which deterioration was apparent (again, more prominent at $\left.30^{\circ} \mathrm{C}\right)$.

Of particular interest was the differential response by pollen lots (data not shown). Our best lot, determined by assay response, remained stable and showed the least deterioration in conductivity over time when compared to our poorest lot. It is also interesting to note that conductivity values at $10^{\circ} \mathrm{C}$ were unaffected by exposure time and, in fact, at 100\% RH actually improved (lower conductivity values indicate more stable membranes). Values for $20^{\circ} \mathrm{C}$ showed an intermediate response.

Germination results led to similar conclusions. In addition to an ageing effect, which was accelerated by $30^{\circ} \mathrm{C}$ and $100^{\circ} \mathrm{C} \mathrm{RH}$, there was also a shock effect which was prevalent in the early stages of hydration and most severe for $30^{\circ} \mathrm{C}$. It was less severe for $10^{\circ} \mathrm{C}$ and not observed at all for $20^{\circ} \mathrm{C}$. Again, the poorest lot seemed to be more sensitive than the best one.

Table I. Correlation coefficients between 3 in vivo viability assays and in vivo seed yields (\% Fspc) for Douglas fir pollen comparing the effect of 4 moisture contents (MC) and 2 hydration (hyd) levels.

\begin{tabular}{|c|c|c|c|c|c|c|}
\hline \multirow[t]{3}{*}{ Assays } & \multicolumn{6}{|c|}{ Correlation coefficients ${ }^{a}$} \\
\hline & \multicolumn{4}{|c|}{ effect of $\% M C$} & \multicolumn{2}{|c|}{ Prehydration ${ }^{b}$} \\
\hline & $4 \%$ & $8 \%$ & $12 \%$ & $16 \%$ & no hyd & hyd \\
\hline $\begin{array}{l}\text { Resp } \times \% \text { Fspc } \\
\% \text { Cond } \times \% \text { Fspc } \\
\% \text { Germ } \times \% \text { Fspc }\end{array}$ & $\begin{array}{r}0.393 \\
-0.137 \\
0.087\end{array}$ & $\begin{array}{r}0.547 \\
-0.654 \\
0.328\end{array}$ & $\begin{array}{r}0.758 \\
-0.848 \\
0.843\end{array}$ & $\begin{array}{r}0.565 \\
-0.703 \\
0.768\end{array}$ & $\begin{array}{r}0.911 \\
-0.595 \\
0.284\end{array}$ & $\begin{array}{r}0.865 \\
-0.841 \\
0.766\end{array}$ \\
\hline
\end{tabular}

a Data from unpublished results.

b Hydration of pollen at $100 \% \mathrm{RH}$ for $16 \mathrm{~h}$ at $25^{\circ} \mathrm{C}$. 
A

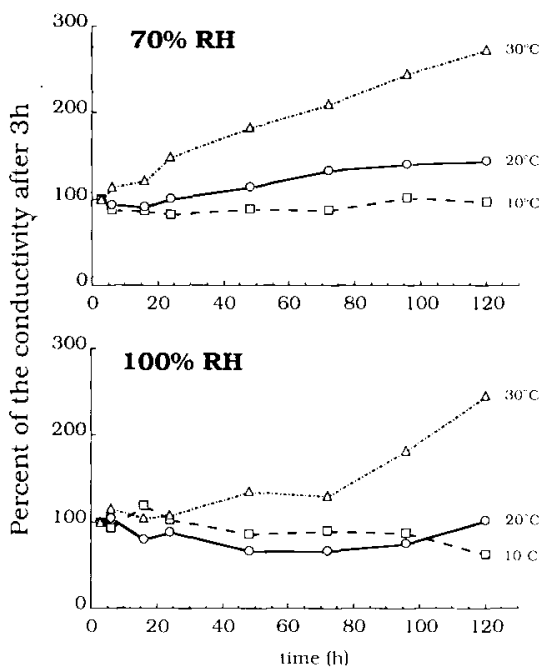

B

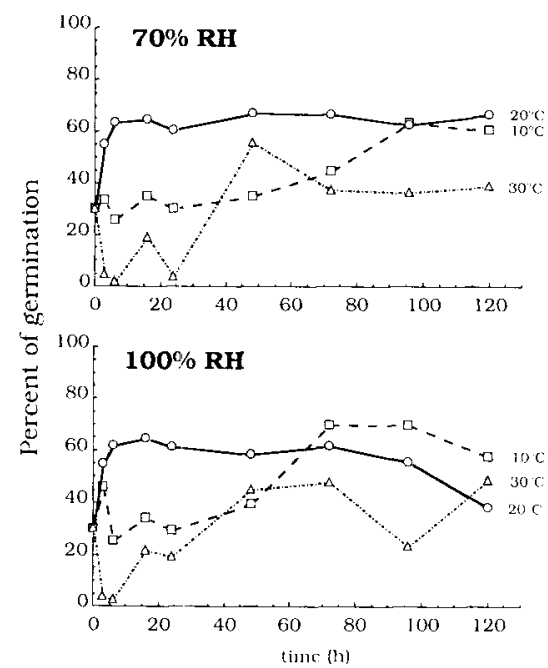

Fig. 1. Effect of air humidity, temperature and hydration duration on (A) conductivity (expressed as the \% of the measurement atter $3 \mathrm{~h}$ under these conditions) and (B) germination (expressed as the \% of class 1 grains).

\section{Conclusion}

Correlating the response of a particular pollen lot to in vivo fertility is largely dependent upon its moisture content. Since most lots in storage are dehydrated to less than $10 \% \mathrm{MC}$, prehydration usually improves the viability response. This is particularly true for germination and conductivity but apparently not for respiration.

Regarding the effects of hydration on germination, results from pollen hydrated at $70 \% \mathrm{RH}$ suggest that membranes may be fully reactivated compared to $100 \%$. However, the negative impact of $30^{\circ} \mathrm{C}$ (at $70 \% \mathrm{RH}$ ) is observed immediately and affects the poorer lots more. Hydration at $10^{\circ} \mathrm{C}$ appears to be best for stabilizing and, indeed, improving pollen membranes (lower conductivity), but germination results are not as good as for $20^{\circ} \mathrm{C}$. It is also apparent that the germination response is highly variable, suggesting that the source of this variation should be determined.

Data collected from this and previous tests suggest that prehydrating Douglas fir pollen before in vivo testing is essential and that current procedures $(100 \% \mathrm{RH} / 16$ $\mathrm{h} / 20^{\circ} \mathrm{C}$ ) are still acceptable. In white spruce (Picea glauca), however, these hydration conditions did improve the correlation between germination and yield but had little or even negative effects on other assay responses (Webber, unpublished data). Work must continue to evaluate the effect of hydration on viability responses for all species and, in particular, investigate the effect of hydration at low temperature on in vivo fertility (Mellerowicz and Bonnet-Masimbert, 1986). 


\section{References}

Charpentier J.P. \& Bonnet-Masimbent M. (1983) Influence d'une réhydratation préalable sur la germination in vitro du pollen de Douglas (Pseudotsuga menziesii) après conservation. Ann. Sci. For. 40, 309-317

Kerhoas C., Gay G. \& Dumas C. (1987) A multidisciplinary approach to the study of the plasma membrane of Zea mays pollen during controlled dehydration. Planta 171, 1-10
Mellerowicz E. \& Bonnet-Masimbert M. (1986) Importance de la teneur en eau du pollen pour la réalisation de croisements contrôlés chez le Douglas. Ann. Sci. For. 43, 179-188

Shivanna K.R. \& Heslop-Harrison J. (1981) Membrane state and pollen viability. Ann. Bot. 17, 759-770

Webber J.E. (1987) Increasing seed yield and genetic efficiency in Douglas fir seed orchards through pollen management. For. Ecol. Manage. $19,209-218$ 